\title{
COVID-19 Pandemic: Looking in the mind of students during lockdown
}

\author{
Ravi Kant ${ }^{1}$ \\ Associate Professor, Department of Teacher Education, School of Education, \\ Central University of South Bihar, Gaya, India. \\ edu.ravikant@gmail.com
}

\begin{abstract}
Entire world is facing unprecedented Corona pandemic. No one was expected that due to this pandemic entire life style of man will be changed. In the course of prevention of spread of the Corona infection, all public institution is lock downed including educational institutions. Several weeks long isolation (social distancing) creating some psychological and emotional problems among students. This research is a survey based descriptive analysis to explore the effects of COVID-19 lock down on the thinking pattern and emotional behavior of students of Central University of South Bihar, Gaya. Using snowball sampling a Google survey form was used to collect the data. This form consist 21 items regarding emotional, social and psychological aspect of students during the COVID-19 lockdown. Maximum items are to be answered in Yes or No and some items are given another option can't say. Total 243 dully filled responses were received. There were 134 male and 109 female who participated in online survey. Results reveals that maximum students were found worried and anxious about their study and Corona spread. They were feeling panic due to the regular increasing number of Corona's infections. This long duration COVID-19 lock down affected the thinking pattern of students. Now they were more sensitive and inquisitive towards social issues and problems. Research suggests that some counseling sessions should be provide to the students to make them enable to cope up with the current situations.
\end{abstract}

Keywords: COVID-19, Pandemic, Corona virus, University's students

\section{Introduction}

Entire world is passing though a very pathetic situation due to the pandemic of Corona virus. No one think that one day due the smallest creature of nature, every human activity will badly affect. This is first time when everyone is scaring form one another. As far there is no authentic cure is available in medical field other than 'Social distancing'. Entire world is following social distancing and the developing and over populated country like India is practicing social distancing and implemented "Lock down" for preventing the spread of Corona virus. India becomes largest democracy in the world implementing and following lock down in serious manner.

Lock down is a situation in which government restricted the opening of the markets, offices, public places, transport facilities in course to prevent the social contacts and human gathering. Peoples are expected to stay in their homes and allow coming out only for the essential needs or in any urgency.

Affecting around 37,336 people in India (updated 02 May 2, 2020), the virus has changed the very rhythm and routine of everyone's life. Peoples are staying in their home in order to break the chain of spreading of Corona virus. A long period spending in home is creating some psychological and emotional changes in the people of every age. Maintaining social distancing is proving very helpful in the fight again Corona virus but on other hand this has a great effect on the mental and emotional status of students and adults.

A major adverse consequence of the COVID-19 pandemic is likely to be increased social isolation and loneliness (as reflected in our surveys), which are strongly associated with anxiety, depression, self-harm, and suicide attempts across the lifespan It was observed that when any infectious disease spread in the mass it trigger waves of fear and anxiety among the persons. This fear or anxiety turns in to disruption of mental well being and emotional behavior of human ${ }^{[1]}$.

In another study COVID-19 found that responders had a moderate level of knowledge about the COVID19 infection and adequate knowledge about its preventive aspects. The attitude towards COVID19 showed that peoples are following all guidelines about social distancing issued by government. . The anxiety levels identified in the study were high. More than $80 \%$ of the people were preoccupied with the thoughts of COVID-19 ${ }^{[2]}$. 
There was high prevalence of mental health problems, which positively associated with frequently Social Media Exposure during the COVID-19 outbreak. Peoples were found more panic and were using more Social Media Platform to gain latest information regarding Corona pandemic ${ }^{[3]}$.

This research is a effort to investigate few aspects of emotional and mental health of students during COVID-19 lockdown.

\section{Materials and Methods}

This was a survey based study carried out among students of Central University of South Bihar, Gaya. A purposive random sampling technique was used. An online questionnaire was developed by using Google forms, with a consent form appended to it. The link of the questionnaire was sent through emails, WhatsApp and other social media platforms to the students registered in all courses of all levels of Central University of South Bihar. The participants were encouraged to roll out the survey to as many people as possible. On receiving and clicking the link the participants got auto directed to the information about the study and informed consent.

After they accepted to take the survey they filled up the demographic details. Then a set of several questions appeared sequentially, which the participants were to answer.

As it was an online study so participants with access to the internet could participate in the study. The data collection was initiated on 19 March 2020 at 4:00 PM and closed on 25 March 2020 at 5:00 PM.

There were total 21 items regarding emotional, social and psychological aspect of students during the COVID-19 lockdown. Maximum items are to be answered in Yes or No and some items are given another option can't say. Descriptive statistics have been used in the study to analyze the findings.

Total 243 dully filled responses were received. There were 134 male and 109 female who filled the online questionnaire. Following is the detail description of the participants-

Table 1 showing the distribution of participants

\begin{tabular}{llcl}
\hline Variables & & N & \% \\
\hline Gender & Male & 134 & 44.90 \\
& Female & 109 & 55.10 \\
& & & \\
Residential Location & Urban & 96 & 39.50
\end{tabular}

\begin{tabular}{|c|c|c|c|}
\hline & Rural & 83 & 34.20 \\
\hline & Semi-urban & 64 & 26.30 \\
\hline \multirow[t]{4}{*}{ Level of study } & Under & 135 & 55.60 \\
\hline & Graduate & & \\
\hline & Post Graduate & 86 & 35.40 \\
\hline & Ph.D. & 22 & 09.10 \\
\hline \multirow[t]{4}{*}{ Discipline } & Education & 109 & 44.90 \\
\hline & Science & 57 & 23.50 \\
\hline & Social Science & 40 & 16.50 \\
\hline & Law & 37 & 15.20 \\
\hline \multirow[t]{5}{*}{ Source of Information } & $\begin{array}{l}\text { Social Media } \\
\text { platform }\end{array}$ & 108 & 44.44 \\
\hline & $\begin{array}{l}\text { Electronic } \\
\text { Media }\end{array}$ & 97 & 39.91 \\
\hline & Friends/Parents & 22 & 09.05 \\
\hline & Print Media & 12 & 04.93 \\
\hline & Others & 04 & 01.64 \\
\hline
\end{tabular}

\section{Results and Discussion}

Results of this study are as follow-

Table 2 details of responses (item wise)

\begin{tabular}{|c|c|c|c|}
\hline Item/Question & $\begin{array}{l}\text { Yes } \\
\mathrm{N} \\
(\% \\
)\end{array}$ & $\begin{array}{c}\text { No } \\
\mathbf{N} \\
(\%)\end{array}$ & $\begin{array}{c}\text { May } \\
\text { be/Ca } \\
\text { n't say } \\
\text { N }(\%)\end{array}$ \\
\hline $\begin{array}{l}\text { 1. Do you know/aware } \\
\text { about the general } \\
\text { symptoms of Corona } \\
\text { Virus? }\end{array}$ & $\begin{array}{c}241 \\
(99.20)\end{array}$ & $\begin{array}{r}02 \\
(0 . \\
80)\end{array}$ & - \\
\hline $\begin{array}{l}\text { 2. Do you feels that } \\
\text { Corona becomes a } \\
\text { great challenge in these } \\
\text { circumstances for all of } \\
\text { us? }\end{array}$ & $\begin{array}{r}232 \\
(95.9 \\
0)\end{array}$ & $\begin{array}{r}10 \\
(04 \\
.10 \\
)\end{array}$ & - \\
\hline $\begin{array}{l}\text { 3. Do you feel } \\
\text { uncomfortable when } \\
\text { comes to know about } \\
\text { continuously }\end{array}$ & 216 & 14 & $\begin{array}{c}13 \\
(5.34)\end{array}$ \\
\hline
\end{tabular}


increasing the numbers (88. $\quad$ (5.76

of Corona's infected 88) )

persons?

4. Do you think your $208 \quad 24$

study is being affected

during COVID-19

lockdown?

5. Due to COVID-19

lockdown you have

more time to study. Do

you spending more

time on your study in

comparison to usual

time?

6. Do you feel any

insecurity when you

come to know about

the worse effect of

Corona on human?

7. Do you feel any

emotional instability

during COVID-19

lockdown?

(85. $\quad(9.90$

$84 \quad 159$

(34. $\quad(65.4$

60) 0 )

$213 \quad 30$

(87. $\quad(12.3$

70) 0$)$

$119 \quad 124$

(49. $\quad(51.0$

00) 0$)$

8. You are spending more time with your family now. Do you feel that you are feeling more attachment for your family?

9. Do you feel yourself panic when comes to know about the Corona's infected person nearby your locality or place?

10. Are you worried about your study this time?

11. Do you feel any sensation while watching news about Corona on different News channels?

12. Do you feel yourself more spiritual in COVID-19 lockdown?
$214 \quad 29$

(88. $\quad(11.9$

10) 0)

$164 \quad 79$

(67. $\quad(32.5$

50) 0)

$206 \quad 37$

(84. $\quad(15.2$

80) 0)

$174 \quad 69$

(71. $\quad(28.4$

60) 0 )

$105 \quad 138$

(43. $\quad(56.8$
13. Do you feel that social media platforms are filling your gap of social isolation?

14. Do you think that you should not bother about what is happening in the society due to Corona pandemic?

15. Do you think that in the Corona pandemic you should do something for the needy people but you are not able to do this due to fear of Corona's infection?

16. Do you spend some time in the day in solitude or meditation so that you can keep yourself calm?

17. Do you experience physical fatigue or inertia due to being in the house in this COVID-19 lockdown?

18. Do you think the $217 \quad 26$ challenges and pressure in your studies will increase after this Corona pandemic?

19. Do you think that this Corona pandemic has affected your thinking about the social structure and social problems?

20. Do you think that this Corona pandemic has made you even more sensitive about social problems?
159

84

(65. $\quad(34.6$

40) 0)

$57 \quad 186$

(23. $\quad$ (76.5

50) 0)

$175 \quad 68$

(72. $\quad(28.0$

00) 0 )

$143 \quad 100$

(58. $\quad(41.2$

80) 0)

$146 \quad 97$

(60. $\quad(39.9$

10) 0)

(89. $\quad(10.7$

30) 0)

$195 \quad 48$

(80. $\quad(19.8$

20) 0)

$219 \quad 24$

(90. $\quad(9.90$

10) ) 


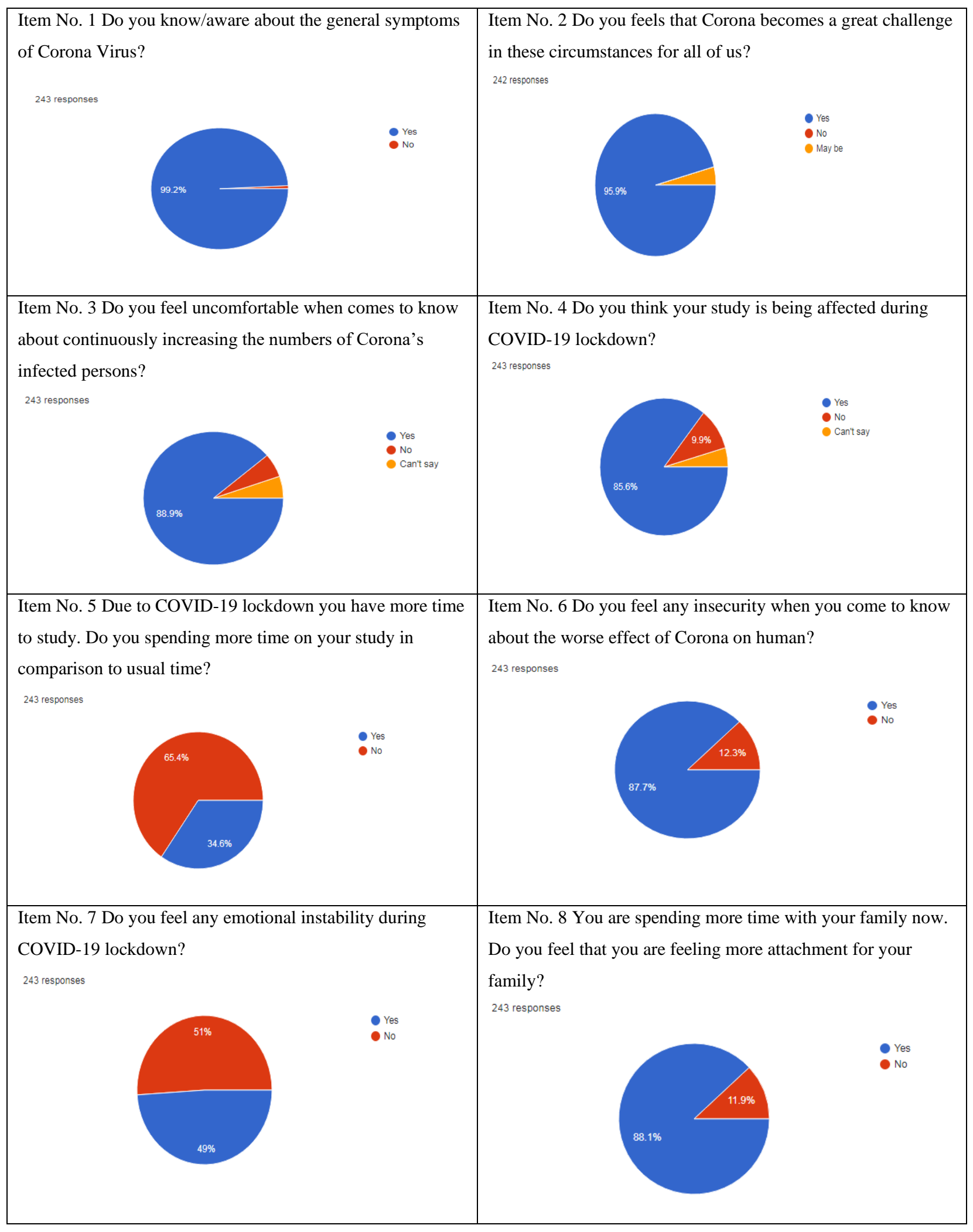




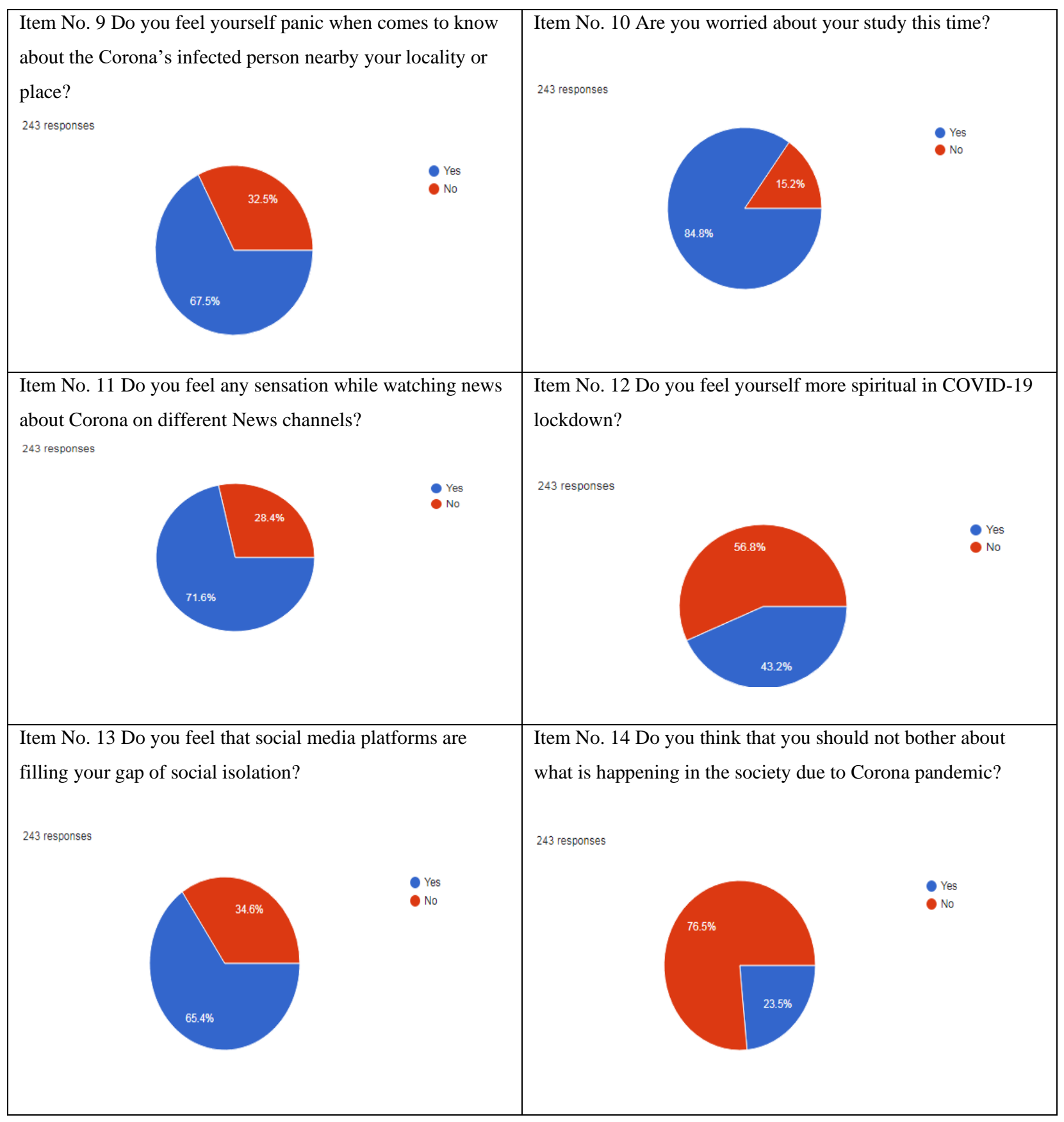




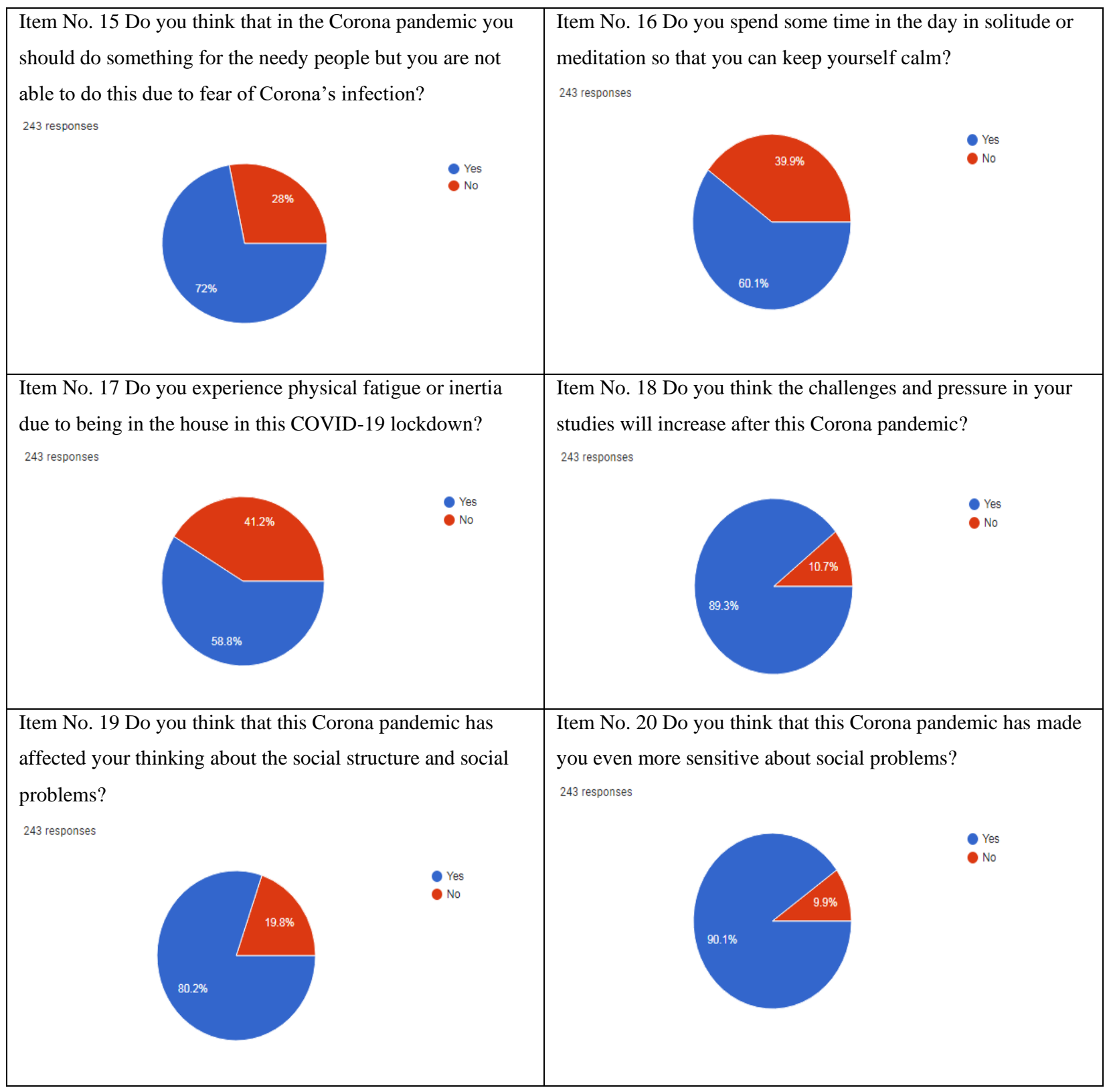

\section{Conclusions and Recommendations-}

Following are the conclusions of the study-

- As per the findings it is clear that most of the students receive information about Corona from social media platform and electronic media. Small number of students got inofrmation from print media and friends \& parents. It is clear that social media and elctronic media is spreading the news and information very quickly and these platforms are very popular and accessibe among students of Central University of South Bihar.
All most students of Central University of South Bihar, Gaya are $(99.20 \%)$ aware about the general symptoms of Corona. This is due to the awareness created by different agencies and government with the help of social media and other electronic media. This is a good sign that students are taking information seriously about the Corona.

- $\quad$ As per the diagram $95.90 \%$ students consider Corona as a great challenge for everyone. They showed there agreement on that this pandemic has a worst effect on everyone's life.

- $\quad$ Statistics shows that $88.88 \%$ students feel uncomfortable due to the increasing numbers of Corona's victim. Only $5.76 \%$ feel that they are not feeling such type of 
feelings. $5.34 \%$ say that they cannot say anything on this. It is clear that maximum students are worried about their health and they are taking seriously their health issue.

- 208 out of 243 students accepted that they their teaching is affected by this Corona lockdown. When this lockdown imposed that was the peak time of student's study. Students are not having books or notes so they are not able to continue with their study. Only 25 students reveals that they don't think that their study affected by any means.

- $\quad$ Only $34.60 \%$ students were spending more time on their study but on other hand $65.40 \%$ students were not spending more time on their study. One possible reason

behind this may be that due to the complete lockdown students are not concentrating on their study. They are worried about their health and study.

- $\quad$ Half of the respondent (49\%) feel emotional instable and half $(51 \%)$ does not feel so. Corona pandemic creating a adverse effect on the emotional behavior of everyone. Who they are little bit less emotional intelligent becoming easy victim of emotional instability. They always think about their health and future and worried about the worse effect of corona pandemic. Because students are socially isolated due to lockdown this may also responsible for the emotional instability.

- During the lockdown peoples are spending more time with their family. In normal life style because to study, job, business they found less time to interact with their family and family members. But COVID-19 lockdown providing them an opportunity to stay all the time with the family. $88.10 \%$ students admit that they are feeling more attachment with their family but rest of them does not feels so.

- $\quad$ Every news channels is broadcasting news about Corona in a different way. 174 participants admit that they feel sensational during the news regarding Corona pandemic but 69 participants denied. Sensational news sometime creates panic among the viewers.

- $\quad$ Surprisingly only 105 (43.20\%) participants revealed that they became more spiritual during Corona lockdown. But $138(56.80 \%)$ rejects that they are more spiritual in this lockdown.

- $\quad$ However there is no ban on Internet and students are continuously using social media platforms but they are also feeling that real social media platforms can't replace the real social contacts and relationship. Only $34.60 \%$ students accepted that social media platform are not capable to fill the gap of social isolation but on other side $65.40 \%$ students are agreed that social media platform are filling their gap of social isolation.

- $\quad$ Showing their social concern about corona pandemic 186 students showed their interest in this social problem. 57 students believes that they should not bother with pandemic and its effects on society.
It is a good sign that $72 \%$ respondents are concerned about the help of needy person but they are equally feared from corona's infection. Only $28 \%$ were not concerned on this issue.

- Yoga, meditation and solitude are the means to maintain equilibrium in our physical, mental and emotional behavior. These are the drastic need in this panic environment of Corona. Fortunately majority of students $(58.80 \%)$ are spending some time of daily routine in yoga and meditation. But also a big chunk (41.20\%) is not spending any time on mediation. This may because of their unawareness or unhealthy life style.

- $\quad$ A long stay at home may also cause fatigue or inertia among students. They are not allowed to go outside; even they are not allowed to play in field. Social media and other means have their own limitations. Long stays with limited physical activities are responsible for fatigue or inertia. $60.10 \%$ students are feeling fatigue or inertia during this COVID-19 lockdown.

- $\quad$ Maximum participants $(80.20 \%)$ feel that corona pandemic changed their thinking pattern about the social problem and social structure. $90.10 \%$ students admit that they are felling more sensitive toward the social problem. Everyone is worried about corona for their family and also for the society. It is a pleasure moment the students showed their sensible behavior regarding the social problem.

This investigation provides a helicopter view of the problem and anxiety facing by students during lockdown. Maximum students are worried about their studies. They are also anxious about the effects and status of Corona pandemic. Mass of students accepted that they are not spending more time in study because they are much panic and feeling anxious due to the increasing number of Corona infections. They are more concern about their health but some students were spending more time in their study. Long term stay at home developed more attachment towards families among students. New and information broadcasting through digital media make them sensational. Now they become more sensitive and responsible towards the social structure and problems.

It is essential to remove anxiety and mental pressure of students so that they can concentrate more on their study and make them healthy and joyful during lockdown. Online counseling session should be provided them to cope up with these problems. Regular monitoring is also should be there by their mentors and psychiatrists for better results.

Conflicts of Interest: The authors declare no conflict of interest.

\section{REFERENCES}

[1]. Balaratnasingam, S., \& Janca, A. (2006). Mass hysteria revisited. Current Opinion in Psychiatry, 19, 171-174. 
[2]. Deblina Roy, Sarvodaya Tripathy, Sujita Kumar Kar,, Nivedita Sharma, Sudhir Kumar Verma, and Vikas Kaushal (2020) Study of knowledge, attitude, anxiety \& perceived mental healthcare need in Indian population during COVID-19 pandemic, Asian Journal of Psychiatry, 51: 1-6 DOI 10.1016/j.ajp.2020.102083

[3]. Gao J, Zheng P, Jia Y, Chen H, Mao Y, Chen S, et al. (2020) Mental health problems and social media exposure during COVID-19 outbreak. PLoS ONE 15(4): $\quad$ e0231924. https://doi.org/ 10.1371/journal.pone.0231924

[4]. Modi P D, Nair G, Uppe A, et al. (April 02, 2020) COVID-19 Awareness among Healthcare Students and Professionals in Mumbai Metropolitan Region: A Questionnaire-Based Survey. Cureus 12(4): e7514. DOI10.7759/cureus.7514

[5]. Bhagavathula, Akshaya Srikanth., Aldhaleei, Wafa Al.i, Rahmani, Jama.., Javed, Mahabadi Mohammad., Ashrafi \& Bandari, Deepak Kumar(2020) Novel Corona virus (COVID-19) Knowledge and Perceptions: A Survey on Healthcare workers, Preprint published on Posted March 16, 2020 https://doi.org/10.1101/2020.03.09.20033381Coban oglu, C., \& Cobanoglu, N. (2003). The effect of incentives in web surveys: application and ethical considerations.International Journal of Market Research,45(4), 475-488. 